\title{
Pentoxifylline as Adjunctive Therapy in Children with Acute Bacterial Meningitis
}

\section{Pentoxifilina como terapia adjunta en niños con Meningitis Bacteriana Aguda}

Prof. Dra. Celia Martínez de Cuellar, Dra. Dolores Lovera, Prof. Dr. Antonio Arbo. Servicio de Pediatría. Instituto de Medicina Tropical

Introduction. Pentoxifylline, an inhibitor of tumor necrosis factor, has been shown in animal models of acute bacterial meningitis that reduce the host inflammatory response.

Objective. To evaluate the effect of pentoxifylline administrated as adjunctive therapy in the treatment of acute bacterial meningitis in children.

Material and methods. Prospective and open study that included children, between 3 months to 15 years old hospitalized in the Institute of Tropical Medicine, of Asunción, Paraguay, with the diagnosis of acute bacterial meningitis. Patients were randomly assigned, to receive in addition to antibiotic therapy (cefotaxime or ceftriaxone) pentoxifylline, dexamethasone, or neither. The presenting status was recorded and the course of disease monitored with preset criteria. The primary endpoints comprised death and severe neurological sequelae.

Results. Eighty seven children received as adjunctive drug pentoxifylline $(n=35)$, dexamethasone $(n=30)$ and neither $(n=22)$. At admission, the demographic, clinical and laboratory characteristics of the patients were comparable. There were no significant differences among the three groups regarding to the duration of fever and meningeal symptoms after admission. The mortality were comparable (11\% in pentoxifylline, $13 \%$ in dexamethasone and 9\% in control group) (p>0.6). Among the survivor patients, unfavorable outcome (severe sequelae) was observed in $13 \%$, $20 \%$ and $15 \%$ for pentoxifylline-, dexamethasone- and control-group, respectively (p>0.5).

Conclution. The data of the present study do not support the routine use of pentoxifylline as adjunctive therapy for bacterial meningitis in children. Key words: Acute bacterial meningitis; children; pentoxifylline; adjunctive therapy 


\section{Resumen}

Introducción. La pentoxifilina, un inhibidor del factor de necrosis tumoral, se ha demostrado en modelos animales de la meningitis bacteriana aguda que reducen la respuesta inflamatoria del huésped.

Objetivo. Para evaluar el efecto de la pentoxifilina se administra como terapia auxiliar en el tratamiento de la meningitis bacteriana aguda en niños.

Material $y$ métodos. Estudio prospectivo y abierto que incluyó a los niños, entre 3 meses a 15 años de edad hospitalizado en el Instituto de Medicina Tropical, de Asunción, Paraguay, con el diagnóstico de la meningitis bacteriana aguda. Los pacientes fueron asignados al azar para recibir, además de la terapia con antibióticos (cefotaxima o ceftriaxona) pentoxifilina, dexametasona, o ninguno. El estado de presentación se registró y el curso de la enfermedad monitorizó con criterios preestablecidos. Los criterios de valoración primarios comprenden la muerte y secuelas neurológicas graves.

Resultados: Ochenta y siete niños recibieron pentoxifilina drogas como adyuvante $(n=35)$, dexametasona ( $n=$ 30) y no $(n=22)$. Al ingreso, las características demográficas, clínicas $y$ analíticas de los pacientes eran comparables. No hubo diferencias significativas entre los tres grupos en cuanto a la duración de la fiebre y los síntomas meníngeos después de la admisión. La mortalidad fue comparable (11\% en pentoxifilina, $13 \%$ en dexametasona y $9 \%$ en el grupo control) ( $p$ $>0,6)$. Entre los pacientes sobrevivientes, se observó un resultado desfavorable (secuelas graves) en el 13\%, 20\% y 15\% para pentoxifylline-, dexamethasone- $y$ el control de grupos, respectivamente ( $p>$ 0,5).
Conclución. Los datos del presente estudio no apoyan el uso rutinario de la pentoxifilina como tratamiento adyuvante para la meningitis bacteriana en niños.

Palabras claves: La meningitis bacteriana aguda; niños; pentoxifilina; tratamiento adyuvante

\section{Introduction}

Bacterial meningitis is one of the major causes of morbidity and mortality among children throughout the world. Despite potent antibiotics and aggressive care support, mortality rates remain high, mainly in developing world (up to 25-40\%) (1), and up to $50 \%$ who survive are left with significant neurological sequelae, $(1,2)$.

Different studies have demonstrated that cytokines play a central role in the pathogenesis of bacterial meningitis. High levels of TNF, IL-1a, and others such as macrophage inflammatory protein 1 (MIP1) and macrophage inflammatory protein 2 (MIP-2) induce enhanced blood brain barrier permeability, leukocytosis in cerebrospinal fluid, and brain edema (2). Because the degree of inflammation in the subaracnoid space correlates inversely with outcome, different drugs that can decrease the release of cytokines were proposed as adjunctive therapy in infants and children with meningitis in an attempt to reduce the inflammatory response in the CSF and to improve the outcome (3).

Previous studies have shown that dexamethasone used as adjunctive therapy for bacterial meningitis in childhood has a beneficial effect (4). However, although several studies have reported that dexamethasone reduces significantly the case fatality rate in bacterial meningitis (5), 
others work showed different conclusions (6). In addition, the effect appeared to be pathogen specific (Haemophilus influenzae type b, Hib) and limited to hearing loss (4). More recently, several reports from developing countries showed that children with bacterial meningitis treated with dexamethasone exhibit greater mortality (7) or any beneficial effect (8). Also, a recent multicenter observational study including children with meningitis hospitalized in 18 US states found that adjuvant corticosteroid therapy was not associated with survival or time to hospital discharge (9). Thus, the clinical effects of dexamethasone on childhood meningitis remain unclear, and indicate the necessity to explore new alternatives in order to reduce the terrible consequences of bacterial meningitis.

Pentoxifylline dimethylxanthine), a methylxanthine derivative and nonspecific phosphordiesterase inhibitor, has been used for several years for the treatment of intermittent claudication in patients with peripheral and cerebrovascular atherosclerotic disease (10). It has been shown that pentoxifylline can reverse many of the effects of endotoxin and endotoxin-induced cytokines on neutrophil function, eg. superoxide production, degranulation, and adherence to endothelial cells (11). In addition, recent evidence indicates that pentoxifylline inhibits TNF synthesis via the inhibition of phosphodiesterase and the increase of intracellular cyclic adenosine monophosphate (12). In human volunteers, under controlled conditions of endotoxemia, pentoxifylline totaly abolished the endotoxin-induced rise of TNF (13), and multiple works show that pentoxifylline have a beneficial effects on complications where this cytokine plays a role, such as after cardiopulmonary bypass in open-heart surgery, sepsis, acute respiratory distress syndrome or cerebral malaria (14).
In experimental model of bacterial meningitis by $\mathrm{Hib}$, the administration of pentoxifylline decrease the peak of TNF concentration in the cerebrospinal fluid (CSF) and modulate in significant degree the meningeal inflammation, reducing significantly the CSF concentrations of leukocytes, protein and lactate (15). Moreover, in experimental model of bacterial meningitis by $S$. peumoniae, pentoxifylline failed to reduce neuronal damage although showed some antiinflammatory activity (16).

The pentoxifylline regimen has been used previously as an ancillary treatment for cerebral malaria (17). In this work, we evaluate the effect of pentoxifylline, used as adjunctive therapy, in the treatment of acute bacterial meningitis in children.

\section{Material and methods}

Site of the Study. This study was performed at the Pediatric Service of the Institute of Tropical Medicine, located in Asunción, the capital of Paraguay. Asuncion is a city of 750,000 inhabitants, but with an influence area of $1,500,000$ persons. The institution is one of the major reference centers of infectious diseases of the country, and provides medical assistance to low socioeconomical level patients.

Elegible patients. This prospective study included infants of both sexes, between 3 months to 15 years old hospitalized in the institution from January 1996 to January 1999, with the diagnosis of bacterial meningitis. Bacterial meningitis was defined by a positive culture of the CSF and/or blood culture with CSF pleocytosis (>10 cells/ul). Patients with clinical symptoms of meningitis and findings characteristic of bacterial infection on 
examination of the cerebrospinal fluid (pleocytosis >1000/ul, hypoglucorrachia $<10 \mathrm{mg} / \mathrm{dl}$ and hyperalbuminorrachia $>100$ $\mathrm{mg} / \mathrm{dl}$ ), but with negative cultures were also included.

Infants less than 3 months of age or with clinical conditions considered as underlying disease, including infection due to human immunodeficiency virus with a CD4 count less than $1000 / \mathrm{mm}^{3}$, neoplasm, diabetes, congenital cyanotic cardiopathy, chronic suppurative otitis, CSF fistula, hydrocephalus, asplenia, Down syndrome, previous transplant, and chronic ( $>15$ days) use of steroids or other immunosuppresive medication were excluded. Patients with previous episodes of bacterial meningitis, aseptic meningitis, as well as patients who had received parenteral antibiotics before admission were also excluded. The study was approved by the ethics committee of the institution. The aim of the study was explained to the guardian accompanying the child on admission.

Treatment. All patients received as antibiotic cefotaxime $(200 \mathrm{mg} / \mathrm{kg} /$ day every $6 \mathrm{hs})$ or ceftriaxone $(100 \mathrm{mg} / \mathrm{kg} /$ day every 24 hs) and the same fluid hidratation schedule. At admission patients were openly randomized into three groups on the basis of a randomized number table. Group I was given a pentoxifylline (HoechstRoussel Pharmaceuticals Inc) at the doses of $8 \mathrm{mg} / \mathrm{kg} /$ day, through continuous intravenous (IV) infusion. Group II was given dexamethasone sodium phosphate at a dose of $0.15 \mathrm{mg}$ per kilogram every six hours IV and group III any adjuvant drugs (control group). Pentoxifylline and dexamethasone were begun 15 to 20 minutes before the intravenous administration of antibiotics, and was administered for four days. Due the way of administration of the study drugs were different (one continuous and the other intermittent infusion), this study was not blind. Antibiotics were continued for 10 days in all cases except meningococcal meningitis when the course was 7 days. Intravenous fluids were given in maintenance volumes, calculated according to bodyweight, until the patients were able to feed.

Clinical Evaluation. At the time of enrollment and thereafter, all patients were clinically evaluated using a standardized method of data collection. Shock was defined as the finding of a systolic blood pressure lower than the $5^{\text {th }}$ centile for age. Presence of severe coma was defined according to Glasgow score; those patients admitted with a Glasgow score less than 9 were including in this category. Fever was defined as the presence of an axillary temperature $\geq 37.8^{\circ} \mathrm{C}$ or a rectal temperature $\geq 38^{\circ} \mathrm{C}$. After admission, febrile days were considered those with a temperature exceeding mentioned limits. Nutritional status was evaluated by the Gómez scale (weight deficit according to age) (17).

Every child was assessed before discharge for neurological, developmental, visual and hearing difficulties. Hearing was assessed to determine whether behavioral responses were appropriate for age; auditory brainstem responses (ABR) were not carried out systematically. Presence of neurologic sequelae due to meningitis was analyzed using coding system ICD-9 (International Disease Classification, $9^{\text {th }}$ revision) and Herson \& Todd criteria (18). Severe sequelae was defined as those that implied incapacity to be by his / her own, as blindness, non-compensated hydrocephalus, quadriplegia, severe mental deficit and seizures refractory to conventional treatment. Presence of hearing impairment, hemiparesis, hyperactivity, peripheral facial paralysis or subdural collection was considered as minor sequelae (18). 
Laboratory Studies. Cerebrospinal fluid from all patients was examined at the time of the diagnosis and 24 hours after the first dose of the antibiotic. Besides cytochemical analysis, all specimens of cerebrospinal fluid were routinely cultured on blood and chocolate agar plates and thioglycolate broth. Blood samples for culture were obtained from all patients before they began antibiotic therapy.

Statistical analysis. Differences in discrete variables among the treatment groups were evaluated with 2-way contingency tables. The standard $X^{2}$ test was used for comparison of proportions between groups, with the use of Yates' continuity correction in $2 \times 2$ tables. In the event of low expected frequencies, exact $P$ values were obtained from STATA $R$ version 8.2 (STATA corp. LP, College Station, Texas). Differences in continuous variables among the treatment groups were tested by analysis of variance. $P<0.05$ (2tailed) was considered significant.

\section{Results}

Eighty-seven patients were enrolled during the study. After randomization, 35 patients received pentoxifylline, 30 dexamethasone and 22 no adjuvant drug. At baseline, the demographic, clinical and laboratory characteristics of the patients were comparable (Table 1).

Tabla 1. Baseline demographic and clinical characteristics of the patients at admission*

\begin{tabular}{|c|c|c|c|c|}
\hline & $\begin{array}{l}\text { Pentoxifylline } \\
\qquad N=35\end{array}$ & $\begin{array}{c}\text { Dexamethason } \\
\text { e } \\
\mathbf{N}=\mathbf{3 0}\end{array}$ & $\begin{array}{l}\text { Control } \\
\mathrm{N}=22\end{array}$ & $\begin{array}{c}\text { P } \\
\text { valu } \\
\mathbf{e}\end{array}$ \\
\hline Age (months), SD & $20,7 \pm 37,4$ & $22 \pm 35$ & $38 \pm 55$ & 0.16 \\
\hline \multicolumn{5}{|l|}{ Sex } \\
\hline Female & $15(43 \%)$ & $11(37 \%)$ & $8(36 \%)$ & 0.62 \\
\hline Male & $20(67 \%)$ & $19(63 \%)$ & $14(64 \%)$ & 0.62 \\
\hline \multicolumn{5}{|l|}{ Duration of disease } \\
\hline pre-admission (days) & $3,3 \pm 4,3$ & $3.5 \pm 4,4$ & $2.3 \pm 2$ & 0.39 \\
\hline $\begin{array}{l}\text { Previous antibiotic } \\
\text { therapy }\end{array}$ & $8(23 \%)$ & $7(20 \%)$ & $5(23 \%)$ & 0.99 \\
\hline Fever & $32(92 \%)$ & $27(89 \%)$ & $21(91 \%)$ & 0.84 \\
\hline Neck stiffness & $24(68 \%)$ & $20(65 \%)$ & $16(73 \%)$ & 0.73 \\
\hline Seizures & $10(29 \%)$ & $8(27 \%)$ & $10(45 \%)$ & 0.19 \\
\hline Glasgow coma scale, SD & $13.1 \pm 2.6$ & $12.8 \pm 2.3$ & $13.4 \pm 1.5$ & 0.64 \\
\hline $\begin{array}{l}\text { Severe coma } \\
(\text { Glasgow }<9)\end{array}$ & $2(6 \%)$ & $2(7 \%)$ & $1(5 \%)$ & 0.84 \\
\hline Shock & $6(17 \%)$ & $4(13 \%)$ & $6(27 \%)$ & 0.36 \\
\hline \multicolumn{5}{|l|}{ Laboratory data } \\
\hline Hemoglobin < 9 gr/dl & $14(38 \%)$ & $11(53 \%)$ & $9(41 \%)$ & 0.78 \\
\hline $\mathrm{WBC} / \mathrm{mm}^{3}$ (mean, SD) & $15645 \pm 10123$ & $17323 \pm 12180$ & $13771 \pm 68590.29$ & \\
\hline
\end{tabular}


The mean age of the patients were $20,7 \pm 37,4$ months, $22 \pm 35$ months, and $38 \pm 55$ months, for pentoxifylline, dexamethasone and control groups, respectively $(p>0.1)$. Classic symptoms and signs of meningitis were present in a large proportion of the patients (fever in $92 \%$, $89 \%$, and $91 \%$, respectively; vomits in $78 \%, 73 \%$, and $82 \%$, and neck stiffness in $68 \%, 65 \%$, and $73 \%$, respectively). Similarly, the rate of seizures before admission was comparable in the three groups [9 patients $(26 \%)$ in the pentoxifylline group vs $8(27 \%)$ in dexamethasone group vs $10(45 \%)$ in control group] ( $p>0.1)$

One microorganism was isolated in $40 \%, 53 \%$ and $53 \%$ of the patients in the pentoxifylline, dexamethasone and controlgroups, respectively. The main microorganisms cultured in these groups were $H$. influenzae type b (in $23 \%, 43 \%$ and $45 \%$ ) and $S$. pneumoniae (in 14\%, $10 \%$ and $9 \%$ ).

Clinical course and outcome. The mean number of days with fever after beginning antibiotic therapy was comparable: $3.4 \pm 2.9$ days in the pentoxifylline group vs $3.1 \pm 2.6$ days in the dexamethasone group vs $2.8 \pm 3.6$ days in the control group ( $p>0.1)$. More patients in the dexamethasone group had seizures after admission (53\%) as compared with the pentoxifylline group $(17 \%)$ and control patients (35\%) ( $p<$ 0.05).

During hospitalization there was no significant difference among the three groups regarding to the incidence of secondary fever which was observed in $21 \%, 17 \%$ and $35 \%$ of the patients from pentoxifylline, dexamethasone, and controlgroups, respectively $(p>0.2)$. Also the duration of meningeal symptoms in the three groups was similar: $4 \pm 3$ days vs 4.5 \pm 3.8 days vs $4.3 \pm 2.7$ days, for pentoxifylline, dexamethasone, and controlgroups, respectively. Ten patients died (11\%): four $(11 \%)$ in the pentoxifylline group, four $(13 \%)$ in the dexamethasone group and two (9\%) in the control group (no differences among the different groups) $(p>0.6)$.

Among the survivor patients, unfavorable outcome, defined as the presence of severe sequelae, was observed $13 \%, 20 \%$ and $15 \%$ for pentoxifylline, dexamethasone and control-groups, respectively $(p>0.5)$. Similarly, the frequency of any sequelae (severe plus minor) was similar in the three groups: $40 \%$ vs $43 \%$ vs $44 \%$, for pentoxifylline, dexamethasone and control-groups, respectively.

Cytochemical changes of CSF. In the table 2 are shown the changes in WBC, glucose and albumin in the CSF taken after 24 hours of initial treatment. A significant difference was observed when the number of CSF WBC of the second sample in pentoxifylline and control groups was compared with CSF WBC count in dexamethasone group. In the first two groups the number of WBC CSF increased (mean of $4 \%$ ) compared with a remarkable decrease observed in dexamethasone group (from $5.6 \pm 9.6 \times 10^{3} / \mathrm{mm}^{3}$ to $1.3 \pm$ $2.7 \times 10^{3} / \mathrm{mm}^{3}$, a diminution of $\left.77 \%\right)$ ( $\mathrm{p}<$ 0.05). Moreover, the magnitude of change in the level of gluocorrachia and albuminorrachia in second CSF sample was no different among the three groups (table 2). 
Tabla 2. Cytochemical characteristics of CSF in the different study groups

\begin{tabular}{lcccccc}
\hline \multirow{2}{*}{ Group } & \multicolumn{2}{c}{ Leukocytes (x109/L) } & \multicolumn{2}{c}{ Glucose (mg/dL) } & \multicolumn{2}{c}{ Protein (mg/dl) } \\
\cline { 2 - 7 } & At admission & At 24 hs & At admission & At 24 hs & At admission & At 24 hs \\
\hline PTX & $3.3 \pm 5.2$ & $3.4 \pm 5.9$ & $10 \pm 22$ & $41 \pm 17$ & $196 \pm 198$ & $114 \pm 86$ \\
DX & $5.6 \pm 9.6$ & $1.3 \pm 2.7 *$ & $15 \pm 15$ & $27 \pm 30$ & $240 \pm 208$ & $112 \pm 82$ \\
Control & $2.6 \pm 2.9$ & $4.1 \pm 5.4$ & $17 \pm 24$ & $35 \pm 25$ & $191 \pm 80$ & $130 \pm 87$ \\
\hline
\end{tabular}

Values are the mean \pm SD. PTX=pentoxifillyne; DX=dexamethasone;

$* p<0.05$ against other groups.

\section{Discussion and Conclusión}

To improve the prognosis of bacterial meningitis, various experimental and clinical studies have focused on adjunctive therapyincluding dexamethasone, monoclonal antibodies against endotoxin, and nonsteroids anti-inflammatory drugs. Pentoxifylline, a methylxanthine that exerts multiple beneficial effects on the inflammatory cascade by increasing intracellular cyclic adenosine monophosphate (12), has been shown to inhibit in vitro the release of TNF-a by human leukocytes during stimulation with Hib or endotoxin (18), and reduce in animal model of meningitis by Hib the peak TNF concentrations in CSF as well as different CSF inflammatory indices (CSF leukocytes, lactate and protein) (19). Compared to dexamethasone, the approved drugs for adjunctive treatment of bacterial meningitis, pentoxifylline offers advantages: does not affect the penetration of antibiotics in the CSF as was reported with dexamethasone in the setting of decreased inflammation, does not mask signs such as fever that would identify the nonresponsive patient, and lack the multiple adverse effects that have been reported with steroids. Besides these, dexamethasone has the potential to increase the apoptosis neuronal (20). Thus pentoxifylline appear as a good candidate for clinical use.
The results of our clinical trials revealed no evidence of benefit from the use of pentoxifylline for ancillary treatment of bacterial meningitis. There were no differences in the clinical evolution, the mortality as well as the rate of severe sequelae among the three groups of patients. This clinical outcome relates with the absence of improvement in the CSF meningeal inflammation indices by effect of pentoxifylline (as compared to the control group). Although Saez-Llorens et al (17) in animal model of Hib meningitis have found that pentoxifylline decrease faster different indices of meningeal inflammation, in the present study, patients treated with pentoxifylline did not exhibit after 24 hours of initial treatment a significant decreased in the CSF leukocyte count, reduction in albumin CSF level or increasement of glucorrachia.

To our knowledge there are not previous studies that have evaluated pentoxifylline alone as adjuvant drug in bacterial meningitis. Bociaga-Jasik et al (21) in a small study including 42 patients compared the effect of dexamethasone vs dexamethasone plus pentoxifylline on the course of this disease, and found that the combination significantly decrease the mortality and reduce the neurological sequelae of patients with bacterial meningitis; however any patients received pentoxifylline alone. 
The possible reason for not showing any benefit with pentoxifylline in our study when the theoretical arguments look so convincing could be various. First, a significant proportion of patients were admitted to hospital with longer duration of illness (three days vs one day in the Odio el al study) (4) and had received oral courses of antibiotics before presentation ( $>20 \%$ of the patients). It is possible that the inflammatory cascade was very developed for the time of admission of patients that pentoxifylline could not influence in significant degree in the modulation of cytokines or neutrophil/endothelial cell interaction. However, longer preadmission evolution is the most common scenario in developing world. Second, is probable also that the effect of pentoxifylline would be pathogen specific, since in animal model of Escherichia coli o S. pneumonaie meningitis pentoxifylline showed very weak antiinflammatory effects (22). Third, we did not evaluate systematically the audiologic outcome on/after discharge in the patients included in the study. Since a reduction in sensorineural hearing loss with early administration of adjuvant drugs appear as the most significant finding observed in children with bacterial meningitis, we could not evaluate the eventual benefit of pentoxifylline and/or dexamethasone on these important sequelae. The possibility of selection bias was a matter of concern in the study. But the base-line characteristics of the enrolled patients were similar, including one of the most important indicators of severity of bacterial meningitis, the Glasgow coma scale. Although the statistical power of the study was enough to detect a difference of $25 \%$ or more in mortality among the groups, minor differences could be undetected and the results need to be confirmed in a larger study. However, the mortality in the control group was in the range observed in previous studies of our institution (23).
Although patients treated with dexamethasone exhibited faster decrease in the CSF WBC count (one of the most sensible inflammatory indexes of meningeal infection), this laboratory observation did not have clinical impact, since children on adjunctive treatment with dexamethasone did not show less mortality and neurological sequelae. Further, although previous works (5) have reported that the administration of dexamethasone decrease the case fatality rate in patients with bacterial meningitis, other studies (6) showed different conclusions, including greater mortality (2). The same explanation offer for the absence of beneficial effects of pentoxifylline as adjuvant drug in meningitis can be apply for dexamethasone.

The results of our clinical trial in children with bacterial meningitis do not support the use of pentoxifylline as ancillary treatment in bacterial meningitis in children. Similarly, in settings such as ours, in which presentation to hospital is delayed in children who are very sick, adjuvant steroid treatment does not improve outcome, at least the severe neurological sequelae and mortality.

\section{References}

1. Lovera D, Arbo A. Risk factors for mortality in Paraguayan children with pneumococcal bacterial meningitis. Trop Med Int Health. 2005 10:1235-41

2. Basualdo W, Arbo A. Invasive Haemophilus influenzae type $b$ infections in children in Paraguay. Arch Med Res 2004 35: 126-133.

3. Lovera D, Gamarra C, Arbo A. Prevalencia de secuelas auditivas en niños sobrevivientes de meningitis bacteriana aguda, Pediatría (Asunción) 2004; 31:1015.

4. Odio C., Faingezicht I., Paris M, Nassar M., Baltodano A., Rogers J., Saez-Llorens $X$, Olsen K., McCracken G $H$. The beneficial effects of early dexamethasone administration in infants and children with 
bacterial meningitis. $\mathrm{N}$ Engl J Med 1991.324:1525-1531

5. Saukkonen K, Sande S, Cioffe $C$ et al. The role of cytokines in the generation of inflammation and tissue damage in experimental gram-positive meningitis. J Exp Med 1990. 171: 439-448

6. Girgis NI, Farid Z, Mikhail IA, Farrag I, Sultan Y, Kilpatrick ME. Dexamethasone treatment for bacterial meningitis in children and adults. Pediatr Infect Dis J 1989. 8: 848-851.

7. Molyneux EM, Walsh $A L$, Forsyth $H$ et al. Dexamethasone treatment in childhood bacterial meningitis in Malawi: a randomised controlled trial. Lancet 2002. 360: 211-218.

8. Kanra GY, Secmer G, Ceylan M, Ecevit Z, Belgin $E$. Beneficial effects of dexamethasone in children with pneumococcal meningitis. Pediatr Infect Dis J 1995. 14: 490-494.

9. Qazi SA, Khan MA, Mughai $N$ et al. Dexamethasone and bacterial meningitis in Pakistan. Arch Dis Child 1996. 75: 482-488.

10. Peltola H, Roine I, Fernández J, et al. Oral glycerol $v s$. intravenous dexamethasone to improve the prognosis of childhood bacterial meningitis. A placebo-controlled double-blind trial of 654 patients in Latin America. Clin Infect Dis 2007. 45: 12771286.

11. Mongelluzzo J, Mohamad Z, Ten Have TR, Shah SS. Corticosteroids and mortality in children with bacterial meningitis. JAMA 2008. 299: 2048-2055.

12. van Leenen $D$, van der Poll $T$, Levi $M$ et al. Pentoxifylline attenuates neutrophil activation in experimental endotoxemia in chimpanzees. J Immunol 1993 151: 23182325.

13. Strieter RM, Remick DG, Ward PA et al. Cellular and molecular regulation of tumor necrosis factor alpha production by pentoxifylline. Biochem Biophys Res Commun. 1988 155: 1230-1236.

14. Endres S, Fulle HJ, Sinha B, et al. Cyclic nucleotides differentially regulate the synthesis of tumor necrosis factor-alpha and interleukin-1 beta by human mononuclear cells. Immunology 1991 72: 56-60.

15. Zeni $F$, Pain $P$, Vindimian $M$, Gay J-P, Gery $P$, Bertrand $M$, Page $Y$, Page $D$, Vermesch, Bertran J-C. Effects of pentoxifylline on circulating cytokine concentrations and hemodynamics in patients with septic shock: Results from a double-blind, randomized, placebo-controlled study. Crit Care Med 1996 24:207-214.

16. Coimbra R, Melbostad H, Hoyst DB. Effects of of phosphodiesterase inhibition on the inflammatory response after shock: role of pentoxifylline. J Trauma 2004 56: 442-449.

17. Sáenz-Llorens $X$, Ramilo $O$, Mustafa $M$ et al. Pentoxifylline modulates meningeal inflammation in experimental bacterial meningitis. Antimicrob Agents Chemother 1990 34: 837-843.

18. Bruck ZG, Fisher FR, Mader M, Rieckmann $P$, Nau R. Limited efficacy of pentoxifylline as anti-inflammatory agent in experimental pneumococcal meningitis. Clin Exp Immunol 1997 107: 458-461

19. Di Perri G, Di Perri IG, Monteiro GB et al. Pentoxifylline as a supportive agent in the treatment of cerebral malaria in children. J Infect Dis 1995 171:1317-1322.

20. van Furth $A M$, Steenwiljk TA, Langermans $A M$, van Furth $R$. In vitro effect of dexamethasone, pentoxifylline and antiendotoxin monoclonal antibody on the release of proinflammatory mediators by human leukocytes stimulated with Haemophilus influenzae type b. Pediatr Res 1994 35: 725-728.

21. Bociaga-Jasik $M$, Kalinowska-Nowak $A$, Garlicki A, Mach T. The effect of antiinflammatory therapy with dexamethasone and dexamethasone with pentoxifylline on the course of bacterial meningitis. Przegl Lek. 2003 60:710-715.

Fecha de recepción: 06 de abril de 2015

Fecha de aceptación: 13 de agosto de 2015

Solicitud de Sobretiros:

Prof. Dr. Antonio Arbo

Universidad Nacional de Asunción Instituto de Medicina Tropical 